\title{
Ethanolic extract of Casearia sylvestris Sw exhibits in vitro antioxidant and antimicrobial activities and in vivo hypolipidemic effect in rats
}

\begin{abstract}
ESPINOSA, J.1,2; MEDEIROS, L.F.2; SOUZA, A.2; GÜNTZEL, A.R.C.5; RÜCKER, B.4; CASALI, E.A. .34; ETHUR E.M. 5 ; WINK, M.R. ${ }^{\prime}$; TORRES, I.L.S. ${ }^{2 *}$.

'Laboratório de Biologia Celular - Universidade Federal de Ciências da Saúde de Porto Alegre - Rua Sarmento Leite, 245 - 90050-170 - Porto Alegre - Brasil; '2Departamento de Farmacologia - Universidade Federal do Rio Grande do Sul - Rua Sarmento Leite, 500 - 90050-170 Porto Alegre - Brasil; ${ }^{3}$ Departamento de Ciências Morfológicas - Universidade Federal do Rio Grande do Sul - Rua Sarmento Leite, 500 - 90050-170 Porto Alegre - Brasil; ‘ Departamento de Bioquímica - Universidade Federal do Rio Grande do Sul - Rua Ramiro Barcelos, 2600 - 90035-003 - Porto Alegre - Brasil; '5Programa de Pós-graduação em Ambiente e Desenvolvimento - Centro Universitário UNIVATES - Rua Avelino Tallini, 171 - 95900-000- Lajeado - Brasil. *Correspondence author: iracitorres@gmail.com
\end{abstract}

ABSTRACT: The Casearia sylvestris Sw (Flacourtiaceae) is a shrub that occurs in forests of Southern Brazil; its leaves are widely used in folk medicine as a depurative, analgesic, anti-inflammatory and antiulcerogenic agent. The objective of this study was to perform the phytochemical description and to evaluate the pharmacological activities (antimicrobial, antifungal, antioxidant and toxicity) of the ethanolic extract (EE) of C. sylvestris Sw. In addition, we also evaluated the effect of the EE of $C$. sylvestris $S w$ on the glucose levels and lipid profile in blood serum of rats submitted to a model of streptozotocin-induced diabetes. Material and Methods: In vitro assay: the detection of chemical groups was done through chemical reactions with the development of color or precipitate and by chromatographic profile; the antioxidant activity was measured by the method of reduction of DPPH free radical (2,2-diphenyl-1picrylhydrazyl); the Minimum Inhibitory Concentration was evaluated by the broth microdilution method, and the Minimum Bactericide Concentration and the Minimum Fungicide Concentration were performed in Petri dishes; the cytotoxic activity was measured by the Artemia salina test. In vivo assay: diabetic and non-diabetic rats were treated with EE of C. sylvestris Sw $(300 \mathrm{mg} /$ $\mathrm{kg}$ ) for 45 days, and the glycaemia and lipid profile were analyzed. Results: The EE showed a Lethal Dose ${ }_{50}$ of $724.76 \mu \mathrm{g} \cdot \mathrm{mL}^{-1}$ and important antioxidant, fungicide and fungistatic activities. The EE showed better antimicrobial activity regarding the microorganisms Staphylococcus aureus, Escherichia coli and Salmonella setubal. Conclusion: The EE of C. sylvestris Sw produces a significant decrease in triglycerides, total cholesterol and VLDL levels without any significant alteration in the glycaemia. The EE of $C$. sylvestris $S w$ presents antioxidant and antimicrobial activities and it exhibits a potent hypolipidemic effect.

Keywords: antioxidant activity, antimicrobial activity, diabetes, glycaemia, lipid profile.

RESUMO: Extrato etanólico de Casearia sylvestris Sw apresenta atividade antioxidante e antimicrobiana in vitro e efeito hipolipemiante em ratos. Casearia sylvestris $S w$ (Flacourtiaceae) é uma planta comumente encontrada em florestas do sul do Brasil; suas folhas são amplamente utilizadas na medicina popular como depurativa, analgésica, anti-inflamatória e anti ulcerogênica. O objetivo deste estudo foi apresentar uma descrição fitoquímica e da atividade farmacológica (antimicrobiana, antifúngica, antioxidante e toxicidade) do extrato etanólico (EE) da C. Sylvestris Sw. Adicionalmente, procurou-se avaliar o efeito do EE da $C$. Sylvestris Sw sobre os níveis séricos de glicose e perfil lipídico de ratos submetidos a um modelo de diabetes induzida por estreptozotocina. A detecção de grupos químicos foi realizada por reações químicas de coloração ou precipitação, e também por cromatografia; a atividade antioxidante foi mensurada pelo método de redução do DPPH (2,2-difenil-1-picril-hidrazil); a concentração mínima inibitória foi realizada pela técnica de micro-diluição, e concentração mínima bactericida e concentração mínima fungicida foram realizadas em placa de Petri; enquanto a atividade citotóxica foi conduzida pelo teste da Artemia salina. Nos ensaios in vivo,

Recebido para publicação em 04/09/2013

Aceito para publicação em 16/07/2014

10.1590/1983-084X/13_074

Rev. Bras. Pl. Med., Campinas, v.17, n.2, p.305-315, 2015. 
ratos diabéticos e não-diabéticos foram tratado com EE da C. Sylvestris Sw (300mg/kg) por 45 dias, e os níveis glicêmico e perfil lipídico foram medidos. A dose Letal ${ }_{50}$ do EE foi de $724.76 \mu \mathrm{g}$. $\mathrm{mL}^{-1} ;$ mostrando importante atividades antioxidante, fungicida e fungistática e melhor atividade antimicrobiana contra Staphylococcus aureus, Escherichia coli e Salmonella setubal. O EE da C. Sylvestris Sw promoveu diminuição significativa nos níveis de triglicerídeos, colesterol total e VLDL; porém sem efeito significativo nos níveis glicêmicos. O EE da C. Sylvestris Sw, além de apresentar atividade antioxidante e antimicrobiana; possui também potente efeito hipolipidêmico.

Palavras-chave: atividade antioxidante, atividade antimicrobiana, diabetes, glicemia, perfil lipídico.

\section{INTRODUCTION}

Herbal medicine has been used throughout centuries similarly to the modern pharmaceuticals are used nowadays. The Brazilian territory covers a wide range of climates and soil types, providing a large biodiversity. Herbal medicines provide rational means for the treatment of many diseases (Vermani \& Garg, 2002); between them, we call attention to diabetes. This disease is associated with impaired glucose tolerance and lipid metabolism. It is also linked to other common health problems, such as obesity, hypertension and atherosclerosis (Saltiel \& Kahn, 2001; Modak et al., 2007). Although there are many approaches to reduce the ill effects of diabetes and its secondary complications, a lot of people prefer herbal formulations due to lesser side effects and low cost. Thus, screen for natural compounds or their derivatives with biological activity against diseases could provide a thorough knowledge of ethno botanical based on therapies and a rational exploration of new metabolites of therapeutic value.

Casearia sylvestris Sw (Flacourtiaceae) is a shrub that occurs in forests of Southern Brazil and in other countries throughout Latin America (Lorenzi, 2002; Ferreira et al., 2011) and it is popularly known as guaçatonga, chá-de-bugre or cafezinho-do-mato (Lorenzi \& Matos, 2002). The leaves of this plant are widely used in folk medicine as a depurative, analgesic, anti-inflammatory, antiulcerogenic (Ruppelt et al., 1991; Esteves et al., 2005), antiviral (Simões et al., 1999), and antibacterial (Alves et al., 2000). It is also considered as an excellent functional food to heal dermal wounds and against several venoms of snakes (Cavalcante et al., 2007; Cintra-Francischinelli et al., 2008). In addition, previous study showed pronounced antioxidant of Casearia sylvestris Sw (Albano et al., 2013). The screening of medicinal plants presents an avenue for the discovery of new drugs (Ribnicky et al., 2008). Phytochemical screening of Casearia sylvestris revealed the presence of diterpenes, triterpenes, flavonoids, caproic and ellagic acids (Basile et al., 1990; Itokawa et al., 1990; de Carvalho et al., 1998; Borges et al., 2000).

Previous study showed that flavonoids are able to improve the lipid profile in normal rats (Ito et al.,
2008); and the C. sylvestris extract is a flavonoid-rich plant, as demonstrated in phytochemical screening in this study. The antihyperlipidemic activity of $C$. sylvestris was reported in olive oil-loaded mice (Schoenfelder et al., 2008). Nevertheless, there are no studies of $C$. sylvestris action on lipid profile and glycaemia in animal models of diabetes. Therefore, our objective was described phytochemical screening and evaluated the pharmacological activities as antimicrobial, antifungal, antioxidant and toxicity of ethanolic extract of $C$. sylvestris $S w$. In addition, we also evaluated the effect of the ethanolic extract of C. sylvestris Sw on glucose levels and lipid profile in blood serum of male rats submitted to a model of streptozotocin-induced diabetes.

\section{MATERIALS AND METHODS \\ Plant material}

The material was collected for analysis in Lajeado, Rio Grande do Sul, in February 2008. And, it was identified by Professor André Jasper PhD (PPGAD - UNIVATES) and voucher material, under number 2267, was filed in Herbarium of the Museum of Natural Sciences - Centro Universitário UNIVATES.

\section{Preparation of the ethanolic extract (EE) of Casearia sylvestris}

The plant was collect in the city of Lajeado, Rio Grande do Sul, Brazil, during the summer of 2008 and was identified by Professor Eduardo Ethur PhD (Department of Chemistry of Centro Universitário Univates). The dried leaves were minced and extracted with $90 \%$ ethanol/water solution (ethanol:water 9:1), at room temperature, for 7 days. The solution was then totality evaporated and the extract was stored at $-8{ }^{\circ} \mathrm{C}$. The extracts were dissolved in a 3\% Tween 80 solution to the desired concentration, just before use. The ethanolic extract of $C$. sylvestris was administered at concentration of $300 \mathrm{mg} / \mathrm{kg}$ (de Mattos et al., 2007).

\section{Phytochemical Screening}

It consisted of a set of qualitative analysis 
performed with the choice of plant species in order to characterize the chemical composition of substances of plant origin. The detection of chemical groups is done through chemical reactions that show the development of color (phenolics compounds, tannins, coumarins, flavonoids), precipitate (alkaloids) or the presence of foam (saponins). This analysis is extremely important for an initial chemical characterization of the species, which has close relation with the pharmacological activity profile of the plant present. The methodology employed in this screening was adapted from Harborne (1998), Simões et al. (2004) and Brazilian Pharmacopoeia (1988).

\section{Pharmacological activities \\ Antibacterial and antifungal activities of the ethanolic extract (EE) of Casearia sylvestris}

The analysis of the antimicrobial activity of ethanolic extract of $C$. sylvestris was performed using the microdilution method, using ATCC strains (American Type Culture Collection) of the following organisms - Gram Positive Bacteria: Staphylococcus aureus (ATCC 6538p), Staphylococcus epidermidis (ATCC 12228), Bacillus subtillis (ATCC 6633); Gram Negative: Salmonella setubal (ATCC 19796), Escherichia coli (ATCC 25792), Klebsiella pneumoniae (ATCC 10031), Pseudomonas aeruginosa (ATCC 27853); fungi (yeasts): Candida albicans (ATCC 10231), Saccharomyces cerevisiae (ATCC 2601), Cryptococcus neoformans (ATCC 28952), Candida glabrata (ATCC 10231), Candida dubliniensis (CBS 7987). The minimum inhibitory concentration (MIC) was determined by the microdilution method, realized in triplicate. The microbial suspension was prepared on the day of analysis, obtained by adding the inoculum in $5.0 \mathrm{~mL}$ of sterile saline $0.8 \%$ to a standardized amount of microorganisms in solution. This standardization was carried out according to the McFarland nephelometric scale at 0.5 , equivalent to approximately $1.5 \times 10^{8}$ UFC. $\mathrm{mL}^{-1}$ (colony forming units per milliliter). For greater accuracy the amount of inoculum present, followed the recommendations of the NCCLS, whose reading of turbidity was performed in UV-VIS spectrophotometer at $625 \mathrm{~nm}$ wavelengths. We adapted the technique described by NCCLS (2003)[20], using a 96-microwell sterile. From solutions of the ethanolic extract of $C$. sylvestris at a concentration of $20.0 \mathrm{mg} \cdot \mathrm{mL}^{1}$ in dimethyl sulfoxide (DMSO) were applied in microliter aliquots of 100.0 microwells in triplicate. Then there was a series of dilutions of these samples in casein soy broth for bacteria and Sabouraud broth for fungi, previously inoculated, resulting in the following test concentrations: $10,5,2.5,1.25,0.625$ and 0.3125 $\mathrm{mg} \cdot \mathrm{mL}^{-1}$. The standard antibiotic was also applied in serial dilutions from a solution of chloramphenicol 0.2 $\mathrm{mg} \cdot \mathrm{mL}^{-1}$, while the standard antifungal ketoconazole was used in a solution of $1 \mathrm{mg} \cdot \mathrm{mL}^{-1}$. During the test was also carried out control of the medium, inoculum and DMSO. The plates were incubated for 24 hours at $35^{\circ} \mathrm{C}$ for bacteria and 48 hours at $25^{\circ} \mathrm{C}$ for fungi. After this, there was microbial (bacteria and fungi) growth through the presence of turbidity in the wells. The well contains the lowest concentration where no more microbial growth was observed corresponded to the value of the minimum inhibitory concentration (MIC). For the visualization of microbial growth, were applied $10 \mathrm{~mL}$ of a solution of triphenyltetrazolium chloride (TTC) $5 \mathrm{mg} \cdot \mathrm{mL}^{-1}$, which results in red coloration in the wells where there was growth. The culture showed no growth plate was transferred to solid medium (nutrient agar and Sabouraud agar), to determine the minimum bactericidal concentration (MBC).

\section{Antioxidant activity of the ethanolic extract (EE) of Casearia sylvestris}

The reduction potential of DPPH (2,2-diphenyl-1-picrylhydrazyl) from ethanolic extract of $C$. sylvestris was assessed spectrophotometrically as described by Elmastas et al. (2006). It was prepared a methanol solution of DPPH 0.051 $\mathrm{mg} \cdot \mathrm{mL}^{-1}$, in $1.0 \mathrm{~mL}$ of this solution was added to $3.0 \mathrm{~mL}$ of methanol solution of ethanolic extract in concentrations of $0.10,0.06,0.04,0.02,0.01$ and $0.005 \mathrm{mg} . \mathrm{mL}^{1}$. The mixtures were shaken and kept in the dark at room temperature for 30 minutes. The absorbance of the samples and controls were read in UV-VIS spectrophotometer (Perkin Elmer $\lambda 25$ ) at a wavelength of $517 \mathrm{~nm}$ (VIS), which corresponds to the maximum absorption of the free radical under study. The experiment was performed in triplicate, with the control the butylhydroxytoluene (BHT), synthetic antioxidant and quercetin (QUE), a natural antioxidant. The ability of the ethanolic extract of C. sylvestris to reduce the free radical DPPH was calculated according to the following equation: \% Inhibition of DPPH = [(A0 - A1) / A0 × 100]. Where $\mathrm{A} 0$ is equal to the absorbance of the control and $\mathrm{A} 1$ is the absorbance of the samples. For the analysis of the results were used spreadsheet graphics to express the percentage of antioxidant activity.

\section{Cytotoxic activity of the ethanolic extract} (EE) of Casearia sylvestris

For analysis of cytoxicity activity (Figure 4) was used the microcrustacean Artemia saline, a methodology was adapted from Meyer et al. (1992). The samples were diluted to obtain concentrations of 10,100 and $1000 \mu \mathrm{g} \cdot \mathrm{mL}^{-1}$, was applied along the positive control test tubes, in triplicate, leaving rest for 24 hours, drying the solvent. After this, it was applied 10 specimens of $A$. saline in each tube and $0.05 \mathrm{~mL}$

Rev. Bras. PI. Med., Campinas, v.17, n.2, p.305-315, 2015. 
of yeast. The tube was sealed and left to stand for 24 hours to evaluate the Lethal Dose 50 (LD50).

\section{Experimental model Animals}

The experiments were carried out on 60 day-old male Wistar $(180-190 \mathrm{~g})$ rats that was randomized according to the weight and housed in groups of five in home cages made of Plexiglass material $(65 \times 25 \times 15 \mathrm{~cm})$. The animals were maintained at $22 \pm 2{ }^{\circ} \mathrm{C}$ with water and food ad libitum, under a 12:12h light/dark cycle. Experiments were conducted between $08 \mathrm{~h} 00$ and $17 \mathrm{~h} 00$. The protocol was approved by the on the Ethics and Research Committee of Federal University of Health Sciences of Porto Alegre (Number: 608/08), with procedures in accordance with the National Institutes of Health Guide for Care and Use of Laboratory Animals (Publication No. 85-23, revised 1985), the UK Animals Scientific Procedures Act 1986 and the European Community's Council Directive of 24 november 1986 (86/609/EEC).

\section{Chemicals and drugs}

The following chemicals and drugs were used in this study: streptozotocin (STZ) and Tween 80 purchased from Sigma Chemical Co. (St. Louis, MO, USA), NPH insulin and regular insulin (Eli Lilly, São Paulo, SP, Brazil), ketamine (Parke-Davis, São Paulo, SP, Brazil) and xylazine (Bayer, São Paulo, SP, Brazil).

\section{Experimental design}

Before the beginning of experiment, the rats were habituated to the maintenance room by one week. The animals were firstly divided into two groups: non-diabetic (received citrate buffer, $1 \mathrm{~mL} /$ $\mathrm{Kg}$, i.p.) and diabetic groups [received an unique dose of streptozotocin (STZ), $65 \mathrm{mg} / \mathrm{Kg}$, i.p.]. After, each group was divided into three groups, in total six groups: (CC): non-diabetic receiving drinking water by gavage ( $1 \mathrm{~mL} / \mathrm{kg})$; $(\mathrm{CT})$ : non-diabetic receiving $3 \%$ Tween 80 solution by gavage (extract of $C$. sylvestris $S w$ vehicle $-1 \mathrm{~mL} / \mathrm{kg}$ ); (CE): non-diabetic rats treated with ethanolic extract of $C$. sylvestris Sw by gavage (300 mg/kg); (DS): diabetic receiving drinking water by gavage $(1 \mathrm{~mL} / \mathrm{kg})$ and saline s.c.; (DI): diabetic rats receiving drinking water by gavage $(1 \mathrm{~mL} / \mathrm{kg}$ ) and injections insulin s.c. (2 UI/ $\mathrm{kg}$ of regular insulin at 08:00 a.m., and 2-4 UI/kg of NPH insulin at 05:00 p.m.) dose of insulin was adjusted based on the severity of hyperglycemia, in order to maintain their blood glucose below $150 \mathrm{mg} /$ dL (Kowluru, 2003); (DE): diabetic rats treated with ethanolic extract of C. sy/vestris by gavage $(300 \mathrm{mg} /$ $\mathrm{kg}$ ) and saline s.c.

\section{Experimental induction of diabetes in rats}

Rats were injected intraperitoneally with a single dose of $65 \mathrm{mg} / \mathrm{kg} \mathrm{STZ} \mathrm{(Sigma} \mathrm{Chemical} \mathrm{Co.,}$ St Louis, MO, USA), freshly dissolved in citrate buffer $(0.1 \mathrm{~mol} / \mathrm{L}, \mathrm{pH} 4.5)$ as previous described (Vats et al., 2004). Diabetes induction in rats was identified by polydipsia, polyuria and by measuring non-fasting serum glucose concentrations $48 \mathrm{~h}$ after injection of STZ. Rats with a serum glucose level above $300 \mathrm{mg} /$ $\mathrm{dL}$ were selected for experimentation.

\section{Pharmacological Treatment}

The pharmacologic treatment started after the diabetes induction, i.e., 48 hours after STZ administration, and it was applied for 45 days consecutives: once a day, the animals received water (CC and DI), 3\% Tween 80 solution (CT) and ethanolic extract of $C$. sylvestris Sw (CE and DE) by gavage; and twice a day the animals received saline (s.c., DS) and insulin (s.c., 08:00 a.m. and 05:00 p.m., DI).

\section{Determination of blood glucose levels}

Blood glucose levels were monitored using blood glucose test strips and a blood glucose meter (Accu-Check, Roche, Brazil). Non-fasting blood glucose was measured on day 1 (basal), 15, 30 and 45 from blood obtained from the tail vein in all groups.

\section{Determination of serum lipids}

Triglycerides (TG), total cholesterol (TC), LDL cholesterol (LDL-C) and HDL cholesterol (HDL-C) were determined on day 45 using commercial enzymatic kits (Diagnostic Labtest, MG, Brazil). VLDL cholesterol (VLDL-C) was calculated by the Friedewald equation (Friedewald et al., 1972) after measurement of total serum cholesterol, triglycerides and HDL cholesterol as previously reported (Wood et al., 2006). After fasting for $12 \mathrm{~h}$, animals were submitted to anesthesia with xylazine $(0.5 \mathrm{mg} / \mathrm{kg})$ and ketamine $(10 \mathrm{mg} / \mathrm{kg})$ and blood samples collected by cardiac puncture, centrifuged at $3000 \mathrm{rpm}$ for $10 \mathrm{~min}$ and serum samples were obtained.

\section{Statistical analysis}

Data were expressed as mean + Standard Error of the Mean (S.E.M.) or Standard Deviation (S.D.) as indicated. For the antioxidant activity, it was used one-way ANOVA test, followed by Student-Newman-Keuls test when necessary. The cytotoxic activity was calculated from linear regression obtained by Origin Graph version 5.0 program, which allows the calculation of LD50. For confirm the diabetes condition was applied Student $t$ test for independent samples. Repeated measures two-way ANOVA with independent factors diabetes and treatment was performed followed by multiple 
comparisons test (Bonferroni test) when indicated for glucose measures, and two-way ANOVA followed by multiple comparisons (Student-Newman-Keuls test - SNK) for lipid profile. Differences were considered to be statistically significant if $P<0.05$.

\section{RESULTS}

\section{Income}

After removing the solvent in a rotary evaporator, we obtained dark brown extract with a yield of approximately $3.7 \%$.

\section{Phytochemical Screening}

Through the phytochemical screening tests detected the following constituent groups: phenolic compounds, flavonoids, alkaloids, saponins, coumarins and tannins.

\section{Pharmacological activities}

Antibacterial and antifungal activities of ethanolic extract (EE) of C. sylvestris

The EE of C. sylvestris showed activity against the Staphylococcus aureus, Escherichia coli and Salmonella setubal (Table 1). In addition, the EE of C. sylvestris presented also a fungicide activity and be lethal to Saccharomyces cerevisiae and Cryptococcus neoformans, and fungistatic activity characterized by inhibition the growth of Candida albicans, Candida glabrata and Candida dubliniensis (Table 2). For the standard MBC, was found $3,12 \times 10^{-3} \mathrm{mg} \cdot \mathrm{mL}^{-1}$. For the standard MFC was found $1.25 \times 10^{-1} \mathrm{mg} \cdot \mathrm{mL}^{-1}$.

\section{Antioxidant activity of ethanolic extract} (EE) of C. sylvestris

We observed an important antioxidant activity of this extract, where the EE at the lowest

TABLE 1. Minimum Inhibitory Concentration (MIC) and Minimum Bactericidal Concentration (MBC) of ethanolic extract (EE) of C. sylvestris. ${ }^{*}$ Initial concentration of $20.0 \mathrm{mg} \cdot \mathrm{mL}^{-1}$.

\&Standard antibiotic chloramphenicol $0.2 \mathrm{mg} \cdot \mathrm{mL}^{-1}$. NA: Not active.

\begin{tabular}{lcc}
\hline Microorganisms & \multicolumn{2}{c}{$\mathrm{EE}^{*}\left(\mathrm{mg} \cdot \mathrm{mL}^{-1}\right)$} \\
& $\mathrm{MIC}$ & $\mathrm{MBC}$ \\
\hline Bacillus subtilis & 2.50 & 5.00 \\
Staphylococcus aureus & 1.25 & 1.25 \\
Staphylococcus epidermidis & 2.50 & 5.00 \\
Escherichia coli & 1.25 & 2.50 \\
Klebsiella pneumoniae & 5.00 & 5.00 \\
Pseudomonas aeruginosa & 5.00 & 5.00 \\
Salmonella setubal & 1.25 & 2.50 \\
\hline
\end{tabular}

TABLE 2. Minimum inhibitory concentration (MIC) and minimum fungicidal concentration (MFC) of ethanolic extract (EE) of $C$. sylvestris. *Initial concentration of $20.0 \mathrm{mg} \cdot \mathrm{mL}^{-1}$. ${ }^{\text {sStandard antifungal, ketoconazole of }}$ $1.0 \mathrm{mg} \cdot \mathrm{mL}^{-1}$. NA: Not active.

\begin{tabular}{llc}
\hline Microorganisms & \multicolumn{2}{c}{$\mathrm{EE}^{*}\left(\mathrm{mg} \cdot \mathrm{mL}^{-1}\right)$} \\
& MIC & MFC \\
\hline Candida albicans & 5.0 & - \\
Candida glabrata & 5.0 & - \\
Candida dubliniensis & 5.0 & - \\
Cryptococus neoformans & 5.0 & - \\
Klebsiella pneumoniae & 5.0 & 5.0 \\
Sacharomyces cerevisae & 5.0 & 5.0 \\
\hline
\end{tabular}

dose tested showed a significant antioxidant activity. Importantly, BHT concentrations 0.005 and 0.01 $\mathrm{mg} \cdot \mathrm{mL}^{-1}$, like QUE $0.005 \mathrm{mg} \cdot \mathrm{mL}^{1}$ had lower potential to reduce the DPPH radical than in all of the EE concentrations (ANOVA, SNK $P<0.05$ ).

\section{(EE) of C. sylvestris}

This test it was possible to assess the cytotoxic activity and calculate the LD50 value provided by Figure 4 . The behavior of the extract was different in each test performed. According to Meyer et al. (1982), the larger the LD50 value, the lower the degree of toxicity to extract evaluated, as such, the lower the LD50 value found, the greater the toxicity. Then, test the value found for the LD50 was $724.76 \mu \mathrm{g} \cdot \mathrm{mL}^{-1}$, and values of LD50 less than $1000 \mu \mathrm{g} . \mathrm{mL}^{-1}$ are consider toxic samples, however our EE presented moderate toxicity.

\section{Biochemical analysis \\ Effect of ethanolic extract (EE) of $C$. sylvestris on blood glucose}

Initially, $48 \mathrm{~h}$ after the induction of diabetes with STZ i.p., and before the first dose of ethanolic extract or its vehicle, we observed difference between the level of glucose in relation to diabetics (DS, DI and DE) and non-diabetics groups (CC, CT and CE; one-way ANOVA/SNK, $P<0.001$, data not shown) in the first time (day 1).

We found a significant difference in the mean of glycaemia level between diabetic and nondiabetic rats, when diabetic rats presented higher level of glycaemia $(P<0.001)$. We found a significant difference in the mean of glycaemia level among treatment, the animals that received vehicle (tween 80) and insulin presented lower level of glycaemia in comparison to other groups (two-way ANOVA, $P<0.001)$. The $C$. sylvestris treatment for 45 days had no effect on glycaemia in normal or streptozotocininduced diabetic rats (repeated measures two-way 


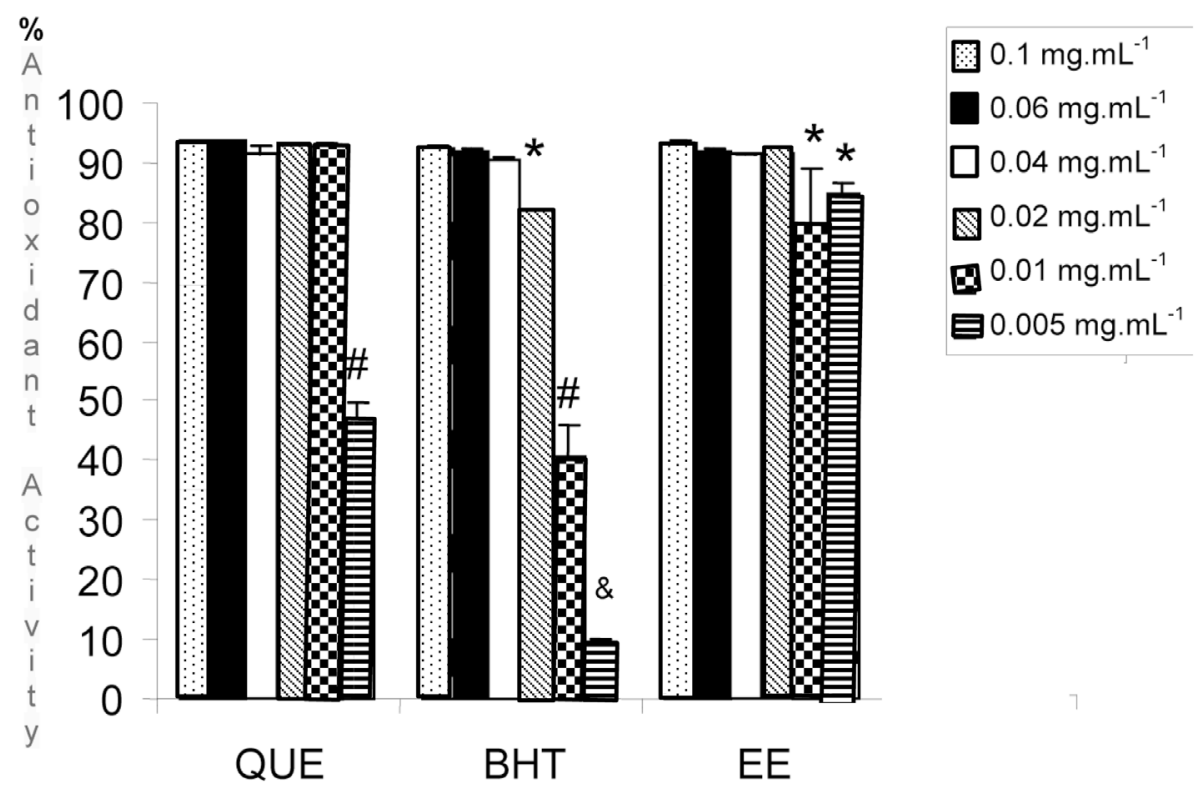

FIGURE 3. Antioxidant activity.

Data expressed as mean \pm S.E.M. of the percentage of antioxidant activity. *groups with similar activities (ANOVA, $P>0.05)$. \# Significant

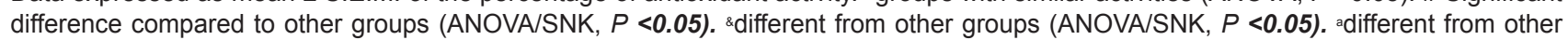
groups that are not flagged as equal to it (ANOVA/SNK, $P<0.05)$. QUE: quercetin, BHT: butylhydroxytoluene, EE: Ethanolic Extract.

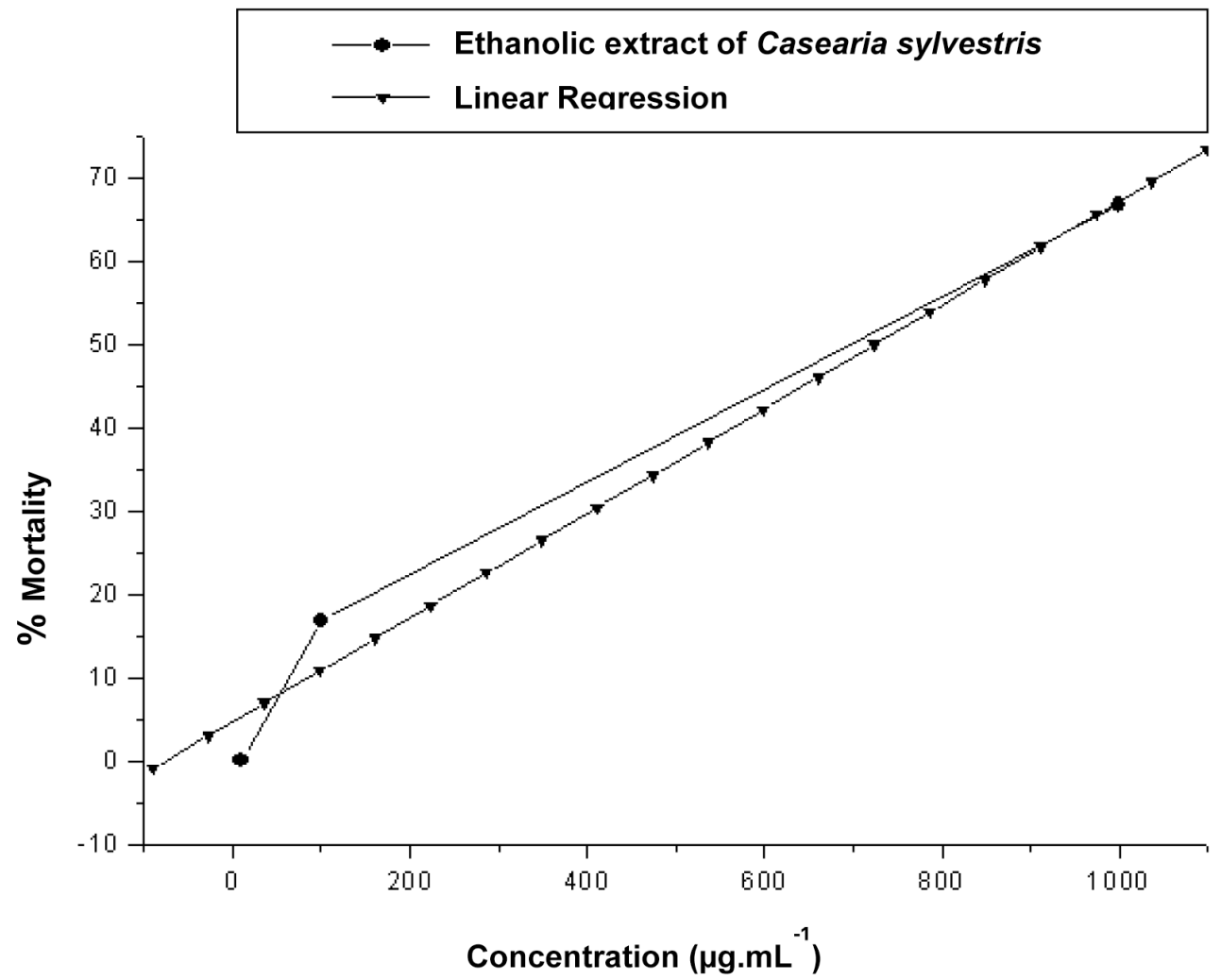

FIGURE 4. Cytotoxicity of ethanolic extract of $C$. sylvestris. $(R=0.98712)$.

ANOVA, $P>0.05, n=6$, Figure 5).

Values presented in $\mathrm{mg} / \mathrm{dL}$ and data were expressed as mean \pm S.D. $(n=6)$. *different from non-diabetic rats (repeated measure two-way ANOVA, $P<0.05) .{ }^{* *}$ different from other groups (repeated measure two-way ANOVA, $P<0.05)$.*** different from other times (repeated measure two- way ANOVA, $P<0.05)$. (CC): non-diabetic receiving drinking water by gavage; (CT): non-diabetic receiving $3 \%$ Tween 80 solution by gavage; (CE): non-diabetic rats treated with EE of $C$. sylvestris $S w$ by gavage; (DS): diabetic receiving drinking water by gavage and saline s.c.; (DI): diabetic rats receiving drinking water by gavage and injections insulin s.c.; 


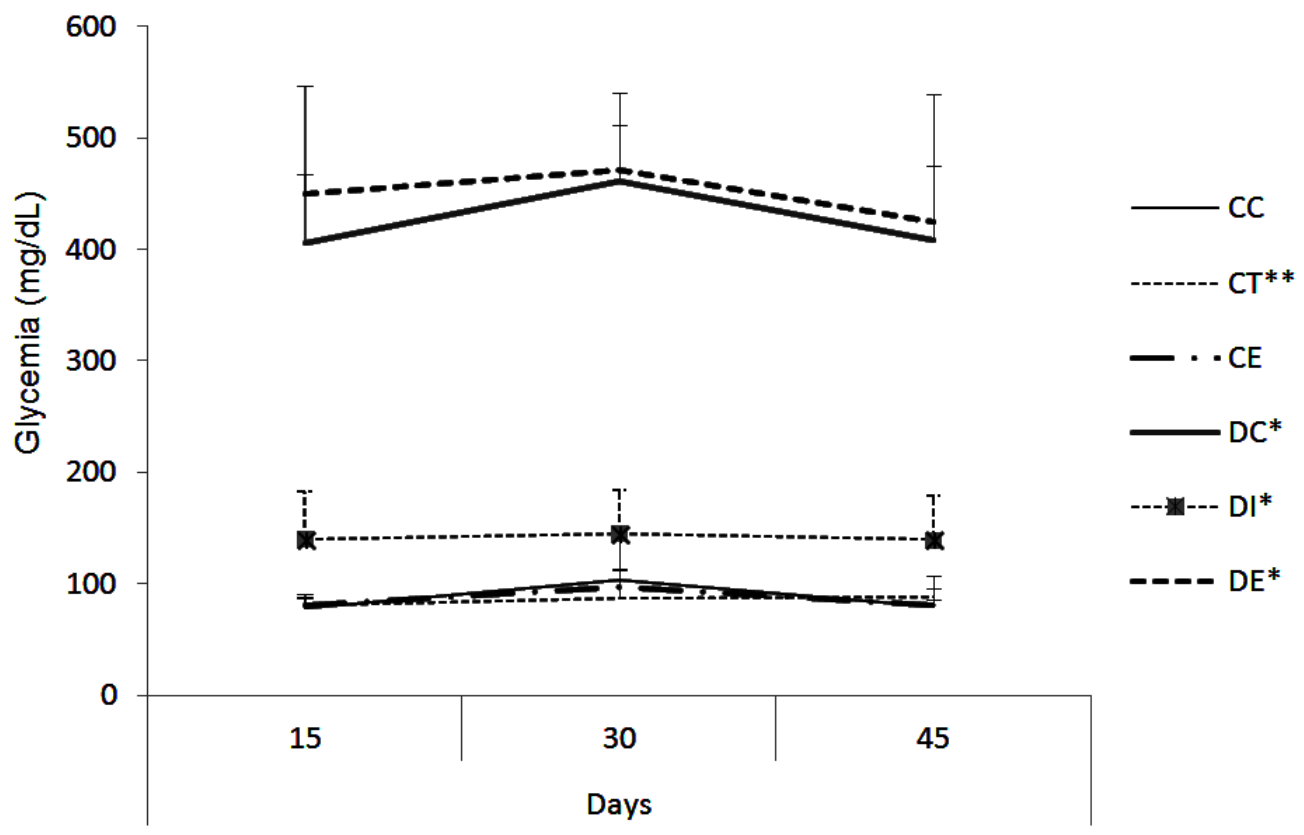

FIGURE 5. Effect of ethanolic extract of Casearia sylvestris on serum blood glucose of rats treated for 45 days.

(DE): diabetic rats treated with EE of C. sylvestris by gavage and saline s.c.

\section{Effect of ethanolic extract (EE) of $C$. sylvestris on lipid profile}

We found significant difference on lipid profile between diabetic and non-diabetic rats, where diabetic rats presented higher levels of triglycerides and VLDL, associated to lower levels of total cholesterol, LDL and HDL (two-way ANOVA, $P<0.01$, Table 3 ).

We observed effect of the treatment by two-way ANOVA $(P<0.05)$. It was observed which animals that received ethanolic extract of $C$. sylvestris presented lower triglycerides and VLDL levels in comparison to other groups (two-way ANOVA/SNK, $P<0.05)$. The total cholesterol level of the animals that received ethanolic extract of $C$. sylvestris presented lower levels in comparison to animals that received water and vehicle (tween 80) by gavage (two-way ANOVA/SNK, $P<0.05$ ). While, the animals that received insulin presented even total cholesterol lower level in relation to other groups (two-way ANOVA/SNK, $P<0.05$ ), and animals that received vehicle (tween 80 ) by gavage presented higher levels than other groups. In the HDL level, animals that received ethanolic extract of $C$. sylvestris and vehicle (tween 80 ) presented higher level in comparison to animals that received water or insulin (two-way ANOVA/SNK, $P<0.05$ ). In relation to the LDL level, animals that received ethanolic extract of $C$. Sylvestris and insulin presented lower level in relation to animals that received water, and animals that received vehicle (tween 80 ) by gavage presented higher levels than other groups (two-way ANOVA/SNK, $P<0.05$, Table 3 ).

In addition, we observed interaction between diabetes and treatment in relation to level of triglycerides, total cholesterol, LDL and VLDL (two-way ANOVA, $P<0.05$ ).

\section{DISCUSSION}

In this study, the EE extract showed an important antioxidant activity, checked by the test of DPPH. In addition, it showed an antioxidant activity higher than the standards $\mathrm{BHT}$ and quercetin in lower concentrations, corroborating a recent study using hydroalcoholic extract of $C$. sylvestris (Albano et al., 2013). In the last years, it has been described the role of free radicals and pro-oxidant molecules in aging, cancer, cardiovascular diseases, and brain dysfunction (Molyneux, 2004). Thus, it is need to study new compounds to protect the body against free radical, and based on our results, we suggest that the potential antioxidant activity observed in our study can be related to the chemical composition of C. sylvestris. It is known that coumarins, flavonoids, lignans and several diterpenes, especially the clerodane (de Carvalho et al., 1998; Tininis et al., 2006) are present, in its composition. The results of the phytochemical screening confirmed the presence of phenolic compounds, alkaloids, flavonoids, saponins, tannins and coumarins. And, phenols 
TABLE 3. Effect of ethanolic extract of Casearia sylvestris on serum lipid profile of rats treated for 45 days.

\begin{tabular}{|c|c|c|c|c|c|}
\hline Group & Total cholesterol & HDL cholesterol & LDL cholesterol & VLDL cholesterol & Triglycerides \\
\hline $\mathrm{CC}$ & $144.33 \pm 10.54$ & $36.00 \pm 3.58$ & $31.67 \pm 4.87$ & $8.33 \pm 0.82$ & $41.17 \pm 4.17$ \\
\hline CT & $163.83 \pm 13.82^{\mathrm{a}}$ & $45.17 \pm 6.62 \mathrm{bc}$ & $84.34 \pm 12.70^{a}$ & $10.83 \pm 2.14 \mathrm{~b}$ & $53.33 \pm 11.18^{b}$ \\
\hline $\mathrm{CE}$ & $130.40 \pm 9.53^{\mathrm{a}}$ & $46.40 \pm 3.51 \mathrm{bc}$ & $37.31 \pm 5.20^{\circ}$ & $5.80 \pm 0.84 a$ & $28.60 \pm 3.29^{a}$ \\
\hline DC & $114.04 \pm 8.06^{*}$ & $26.40 \pm 5.59^{*}$ & $82.40 \pm 7.99^{\star}$ & $49.80 \pm 1.92^{*}$ & $250.00 \pm 9.62^{*}$ \\
\hline DI & $58.25 \pm 15.73^{*_{a}}$ & $31.00 \pm 5.88^{*}$ & $28.12 \pm 11.79^{*_{b}}$ & $13.25 \pm 1.98^{*_{b}}$ & $66.25 \pm 8.97^{* \mathrm{~b}}$ \\
\hline DE & $49.33 \pm 6.35^{\star_{a}}$ & $44.67 \pm 4.03^{*_{b c}}$ & $20.34 \pm 5.57^{*_{b}}$ & $8.33 \pm 2.25^{*_{a}}$ & $40.33 \pm 10.71^{*_{a}}$ \\
\hline
\end{tabular}

Values expressed in $\mathrm{mg} / \mathrm{dL}$ and data were expressed as mean \pm S.D. $(\mathrm{n}=4-8)$. *effect of diabetes (two-way ANOVA/SNK, $P<0.05)$. adifferent

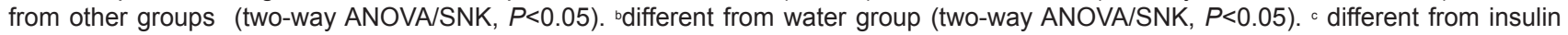
group (two-way ANOVA/SNK, $P<0.05$ ). (CC): non-diabetic receiving drinking water by gavage; (CT): non-diabetic receiving $3 \%$ Tween 80 solution by gavage; (CE): non-diabetic rats treated with EE of C. sylvestris Sw by gavage; (DS): diabetic receiving drinking water by gavage and saline s.c.; (DI): diabetic rats receiving drinking water by gavage and injections insulin s.c.; (DE): diabetic rats treated with EE of C. sylvestris by gavage and saline s.c.

compounds, tannins, flavonoids and coumarin, are generally described with the antioxidant activity (Martín-Sánchez at al., 2014). Deserving emphasis on phenolic compounds and flavonoids that determine the antioxidant activity of the extract of C. sylvestris (Menezes et al., 2004), acting as free radical scavenger. In addition, the EE showed an antimicrobial activity against the microorganisms Staphylococcus aureus, Escherichia coli and Salmonella Setubal. Likewise, the antimicrobial activities can be linked to the presence of saponins, which presents bactericidal and fungicidal activities (Chung et al, 2006).

Additionally, in opposing to popular medicine, the chronic treatment of EE (45 days) did not promote any benefits in the glycaemia serum level of rats. However, it is important to highlight that our model of diabetes induction (STZ) worked very well, the diabetic rats presented high levels of glycaemia. It is important to bring to light that the diabetes model used is involved to the inhibition of biosynthesis and secretion of insulin, culminating in the $\beta$ cells death; and we can not discard that the folk used of $C$. sylvestris may be related to at least in part the production, releasing or action of endogenous insulin. Interestingly, the vehicle (tween 80) presented lower levels of glycaemia in comparison to other treatments (two-way ANOVA); this effect observed showed a limitation of our study, since, we did not have diabetic rats treated with the vehicle (tween 80 ). In the present study, we did not evaluate a possible synergic effect between insulin and $E E$ of $C$. sylvestris $S w$, that it can be considered a limitation of the present protocol.

In relation to diabetic condition, we observed that diabetic rats presented lower levels of total cholesterol and LDL in relation to non-diabetic rats, and these levels were decreased in high proportion after insulin treatment revealed by two-way ANOVA corroborating previous study (Pinheiro et al., 2011).
These rats also presented higher serum levels of triglycerides and VLDL, and this condition was reverted by insulin treatment. In addition, the same animals showed lower level of HDL that did not suffer any influence of insulin treatment. Interestingly, we found reduced levels of total serum cholesterol in diabetic rats in comparison to non-diabetic rats. This finding can be interpreted as high absorption and low synthesis of cholesterol. Streptozotocininduced diabetes in rats hypertrophies intestinal mucosal function, enhancing fat and cholesterol absorption and reducing cholesterol synthesis (Young et al., 1988). It is also known that fasting down regulates cholesterol synthesis and reduction of dietary cholesterol has been observed to effectively reduce serum cholesterol in type 1 diabetic subjects (Kaufmann et al., 1975).

Important results were found in relation to experimental model, we observed that the EE of $C$. sylvestris treatment presented a significant improvement in lipidic profile values in rats (decrease total cholesterol, LDL cholesterol, VLDL cholesterol and triglycerides levels), this corroborates previous study that demonstrated the antihyperlipidemic activity of $C$. sylvestris (Schoenfelder et al., 2008). We highlight the hypolipidemic activity by ethanolic extract of $C$. sylvestris including in a not specific model to develop lipid profile alterations. Moreover, it was observed that the HDL levels were increased for both vehicle tween 80 and ethanolic extract of C. sylvestris treatments, highlighting the vehicle action. However, we call attention that tween 80 also increased the total cholesterol and LDL levels (Table 1) while the ethanolic extract of $C$. sylvestris decreased them, highlighting the action of extract of C. sylvestris. This difference observed by treatment brings to light the protective effect of ethanolic extract of $\mathrm{C}$. sylvestris against cardiovascular diseases.

Previous study showed that flavonoids are

Rev. Bras. PI. Med., Campinas, v.17, n.2, p.305-315, 2015. 
able to improve the lipid profile in normal rats (Ito et al., 2008); and the C. sylvestris extract is a flavonoid-rich plant, as demonstrated in phytochemical screening in this study. The activity of HMG-CoA reductase, the key enzyme of cholesterol biosynthesis, is inhibited by flavonoids and it probably also exerts their influence on steroid metabolism at other pivotal points (Havsteen, 2002; Sung et al., 2004; Min \& Kim, 2007). In diet-induced obesity, tea flavonoids increased fecal excretion of cholesterol and bile acids and reduced cholesterol absorption from intestine (lkeda et al., 1992). These studies indicate that flavonoids modulate lipid metabolism not only in diabetic or obese animals, but also in normal animals. Therefore, we suggest that the flavonoids presents in the extract may account at least in part of the hypolipidemic effect observed in our study.

Many studies showed the inhibition of phospholipase A2 by C. sylvestris (Raslan et al., 2002; Cavalcante et al., 2007; da Silva et al., 2008) and inhibition of cytosolic phospholipase A2 has been reported by suppresses the production of cholesteril ester (li et al., 2008). It may be also another mechanism by which $C$. sylvestris improves the lipid profile.

In contrast, we observed that the diabetic rats showed higher triglycerides levels, it can be characterizing a hyperlipidemic state. There are several reports in the literature trying to explain the possible mechanisms underlying the hyperlipidemia presented by insulin-deficient diabetes (Reaven \& Reaven, 1974; Chen et al., 1979; Rauramma et al., 1980; Tavangar et al., 1992; Gleeson et al., 1999; Hori et al., 2004). Insulin deficiency stimulates lipolysis in adipose tissues, increasing the delivery of free fatty acids (FFA) from adipose tissues to liver and consequently, the production of triglycerides (TG) in liver. Insulin deficiency also reduces plasma lipoprotein lipase (LPL) activity, a key enzyme in plasma lipid metabolism. It hydrolyzes triglycerides (TG) from chylomicrons and VLDL, controls fatty acid uptake into tissues, and releases components for HDL formation (Merkel et al., 2002; Rizos et al., 2005; Loeffler et al., 2007) demonstrated that lipoproteinassociated phospholipase A2 (Lp-PLA2) activity was higher in patients with the metabolic syndrome than in those without it. In addition, increased levels of Lp-PLA2 mass concentration was noted in diabetic patients requiring insulin, suggesting that Lp-PLA2 may raise significantly when the metabolic syndrome is present and $\beta$ cell insufficiency coexists with high insulin resistance (Noto et al., 2006). 3-Hidroxi-3metilglutaril-CoA (HMG-CoA) reductase inhibitors (statins) and fenofibrates can reduce Lp-PLA2 concentrations in plasma, being orally active. Also, specific Lp-PLA2 inhibitors have been developed and tested in clinical trials to evaluate the potential of Lp-PLA2 as a therapeutic target (McConnell \& Hoefner, 2006).

\section{CONCLUSION}

In summary, first, we did not find any improvement in the glycaemia serum level after 45 days of treatment with EE of $C$. sylvestris in a rat model of type 1 diabetes. Second, we suggest that the use of $C$. sylvestris in folk medicine has a high association with the data generated in this study, i.e., the extract has shown significant hypolipidemic effect in rats. We can suggest a possible effect cardioprotective associated to lipid profile enhancement. The exact mechanism(s) underlying the reduction of the cholesterol and triglycerides by the EE of $C$. sylvestris was not investigated in the current study. However, further studies would be required to determine the exact mechanism(s) of lipids lowering effects and site of action of the extract.

\section{Competing interests}

The authors report no conflicts of interest.

\section{REFERENCES}

ALBANO, M.N., da Silveira, M.R., Danielski, L.G, Florentino, D., Petronilho, F., Piovezan, A.P. Anti-inflammatory and antioxidant properties of hydroalcoholic crude extract from Casearia sylvestris Sw. (Salicaceae). Journal of Ethnopharmacology, v.147, n.3, p.612-7, 2013.

ALVES, T.M., Silva, A.F., Brandão, M., Grandi, T.S., Smânia, E., Smânia Júnior, A., Zani, C. L., 2000. Biological screening of Brazilian medicinal plants. Memórias do Instituto Oswaldo Cruz 95, 367-373.

BASILE, A.C., Sertié, J.A., Panizza, S., Oshiro, T.T., Azzolini, C.A. Pharmacological assay of Casearia sylvestris. I: Preventive anti-ulcer activity and toxicity of the leaf crude extract. Journal of Ethnopharmacology, v.30, n.2, p.185-197, 1990.

BORGES, M.H., Soares, A.M., Rodrigues, V.M., AndriãoEscarso, S.H., Diniz, H., Hamaguchi, A., Quintero, A., Lizano, S., Gutiérrez, J.M., Giglio, J.R., HomsiBrandeburgo, M.I. Effects of aqueous extract of Casearia sylvestris (Flacourtiaceae) on actions of snake and bee venoms and on activity of phospholipases A2. Biochemistry and Molecular Biology of Comparative Biochemistry and Physiology, v.127, n.1, p.21-30, 2000.

BRAZILIAN PHARMACOPOEIA. São Paulo: Atheneu. 4 ed, 1988.

DE CARVALHO, P.R., Furlan, M., Young, M.C., Kingston, D.G., Bolzani, V.S. Acetylated DNA-damaging clerodane diterpenes from Casearia sylvestris. Phytochemistry, v.49, n.6, p.1659-62, 1998.

CAVAlCANTE, W.L., Campos, T.O., Dal Pai-Silva, M., Pereira, P.S., Oliveira, C.Z., Soares, A.M., Gallacci, M. Neutralization of snake venom phospholipase A2 toxins by aqueous extract of Casearia sylvestris 
(Flacourtiaceae) in mouse neuromuscular preparation. Journal of Ethnopharmacology, v.112, n.3, p.490-7, 2007.

CHEN, Y.D.I., Risser, T.R., Cully, M., Reaven, G.M. Is the hypertriglyceridemia associated with insulin deficiency caused by decreased lipoprotein lipase activity? Diabetes, v.28, n.10, p.893-898, 1979.

CHUNG J.Y., Choo J.H., Lee M.H., Hwang J.K. Anticariogenic activity of macelignan isolated from Myristica fragrans (nutmeg) against Streptococcus mutans. Phytomedicine, 13(4):261-6, 2006.

CINTRA-FRANCISCHINELLI, M., Silva, M.G., AndréoFilho, N., Gerenutti, M., Cintra, A.C., Giglio, J.R., Leite, G.B., Cruz-Höfling, M.A., Rodrigues-Simioni, L., Oshima-Franco, Y. Antibothropic action of Casearia sylvestris Sw. (Flacourtiaceae) extracts. Phytotherapy Research, v.22, n.6, p.784-790, 2008.

ELMASTAS, M.; Gülcin, I.; Isildak, O.; Küfrevioglu, O. I.; Ibaoglu, K.; Abould-Enein, H. Y. Radical scavenging activity and antioxidant capacity of bay leaf extracts. Journal of the Iranian Chemical Society, v.3, n.3, p.258-266, 2006.

ESTEVES, I., Souza, I.R., Rodrigues, M., Cardoso, L.G., Santos, L.S., Sertie, J.A., Perazzo, F.F., Lima, L.M., Schneedorf, J.M., Bastos, J.K., Carvalho, J.C. Gastric antiulcer and anti-inflammatory activities of the essential oil from Casearia sylvestris Sw. Journal of Ethnopharmacology, v.101, n.1-3, p.191-196, 2005.

FERREIRA, P.M., Costa-Lotufo, L.V., Moraes, M.O., Barros, F.W., Martins, A.M., Caval- heiro, A.J., Bolzani, V.S., Santos, A.G., Pessoa, C., 2011. Folk uses and pharma- cological properties of Casearia sylvestris: a medicinal review. Anais da Academia Brasileira de Ciências 83, 1373-1384.

FRIEDEWALD, W.T., Levy, R.I., Fredrickson, D.S. Estimation of the concentration of low-density lipoprotein cholesterol in plasma, without use of the preparative ultracentrifuge. Clinical Chemistry, v.18, n.6, p.499502, 1972.

GLEESON, A., Anderson, K., Owens, D., Bennett, A., Collins, P., Jhonson, A., White, D., Tomkin, G.H. The role of microsomal triglyceride transfer protein and dietary cholesterol in chylomicron production in diabetes. Diabetologia, v.42, n.8, p.944-8, 1999.

HARBORNE, J.B. Phytochemical methods: a guide to modern techniques of plant analysis. London: Chapman and Hall. 3 ed, 1998.

HAVSTEEN, B. H. The biochemistry and medical significance of the flavonoids. Pharmacology \& Therapeutics, v.96, n.2-3, p.67-202, 2002.

HORI, M., Satoh, M., Furukawa, K., Sakamoto, Y., Hakamata, H., Komohara, Y., Tekeya, M., Sasaki, Y., Miyazaki, A., Horiuchi, S. Acyl-coenzyme A: cholesterol acyltransferase-2 (ACAT-2) is responsible for elevated intestinal ACAT activity in diabetic rats. Arteriosclerosis, Thrombosis and Vascular Biology, v.24, n.9, p.1689-95, 2004.

II, H., Oka, M., Yamashita, A., Waku, K., Uozumi, N., Shimizu, T., Sato, T., Akiba, S. Inhibition of Cytosolic Phospholipase A2 Suppresses Production of Cholesteryl Ester through the Reesterification of Free Cholesterol but not Formation of Foam Cells in Oxidized LDL-Stimulated Macrophages. Biological \& Pharmaceutical Bulletin, v.31, n.1, p.6-12, 2008.

IKEDA, I., Imasato, Y., Sasaki, E., Nakayama, M., Nagao, H., Takeo, T., Yayabe, F., Suganom M. Tea catechins decrease micellar solubility and intestinal absorption of cholesterol in rats. Biochimica et Biophysica Acta, v.1127, n.2, p.141-6, 1992.

ITO Y., Ichikawa T., Morohoshi Y., Nakamura T., Saegusa Y., Ishihara K. Effect of tea catechins on body fat accumulation in rats fed a normal diet. Biomedical Research, v.29, n.1, p.27-32, 2008.

ITOKAWA, H., Totsuka, N., Morita, H., Takeya, K., litaka, Y., Schenkel, E.P., Motidome, M. New antitumor principles, casearins A-F, for Casearia sylvestris Sw. (Flacourtiaceae). Chemical \& Pharmaceutical Bulletin, v.38, n.12, p.3384-8, 1990.

KOWLURU R.A. Effect of re-institution of good glycemic control on retinal oxidative stress and nitrative stress in diabetic rats. Diabetes, v.52, n.3, p.818-23, 2003.

LOEFFLER, B., Heeren, J, Blaeser, M., Radner, H., Kayser, D., Aydin B., Merkel, M. Lipoprotein lipasefacilitated uptake of LDL is mediated by the LDL receptor. Journal of Lipid Research, v.48, n.2, p.288-98, 2007.

LORENZI, H. Árvores Brasileiras. Plantarum, Nova Odessa, p. 131, 2002.

LORENZI, H.; Matos, F.J.A. Plantas Medicinais no Brasil: Nativas e exóticas, Instituto Plantarum de Estudos da Flora LTDA., Nova Odessa, SP, 23-24, 2002.

MARTÍN-SÁNCHEZ A.M., Cherif S., Ben-Abda J., Barber-Vallés X., Pérez-Álvarez J.Á., Sayas-Barberá E. Phytochemicals in date co-products and their antioxidantactivity. Food Chem, 1;158:513-20; 2014.

DE MATTOS, E.S., Frederico, M.J.S., Colle, T.D., de Pieri, D.V., Peters, R.R., Piovezan, A.P. Evaluation of antinociceptive activity of Casearia sylvestris and possible mechanism of action. Journal of Ethnopharmacology, v.112, n.1, p.1-6, 2007.

MCCONNELL, J.P., Hoefner, D.M. Lipoprotein-associated phospholipase A2. Clinical Laboratory Medicine, v.26, n.3, p.679-97, 2006.

MEYER, B.N.; Ferrigni, N.R.; Putmam, J.E.; Jacobsen, L.B.; Nichols, D.E.; Mclaughlin, J.L. Brine shrimp: A convenient general bioassay for active constituents. Planta Medica, v.45, n.5, p. 31-34, 1992.

MENEZES, P.R.; Schwarz, E.A.; Santos, C.A.M. In vitro antioxidant activity of species collected in Paraná. Fitoterapia, v. 75, n.3-4, p. 398-400, 2004.

MERKEL, M., Eckel, R. H., Goldberg, I. J. Lipoprotein lipase: genetics, lipid uptake and regulation. Journal of Lipid Research, v.43, n.12, p.1997-2006, 2002.

MIN, S.W., Kim, D.H. Kakkalide and irisolidone: HMG-CoA reductase inhibrs isolated from the flower of Pueraria thunbergiana. Biological \& Pharmaceutical Bulletin, v.30, n.10, p.1965-8, 2007.

MODAK, M., Dixit, P., Londhe, J., Ghaskadbi, S., Devasagayam, T.P.A. Indian Herbs and Herbal Drugs Used for the Treatment of Diabetes. Journal of Clinical Biochemistry and Nutrition, v.40, n.3, p.163-173, 2007.

MOLYNEUX, P. The use of the stable free radical diphenylpicrylhydrazyl (DPPH) for estimating antioxidant activity. Songklanakarin J Sci Technol, 26(2): 211219, 2004.

NCCLS. Metodologia dos Testes de Sensibilidade a Agentes Antimicrobianos por Diluição para Bactérias 
de Crescimento Aeróbico: NCCLS documento M7-A6, 6.ed., v. 23, n. 02 Pennsylvania, Estados Unidos, 2003.

NOTO, H., Chitkara, P., Raskin, P. The role of lipoproteinassociated phospholipase $\mathrm{A} 2$ in the metabolic syndrome and diabetes. Journal of Diabetes and Its Complications, v.20, n.6, p.343-8, 2006.

PINHEIRO, L.S., de Melo, A.D.,Andreazzi, A.E., de Caires Júnior, L.C., Costa, M.B., Garcia. R.M.G. Protocol of Insulin Therapy For Streptozotocin-Diabetic Rats Based on a Study of Food Ingestion and Glycemic Variation. Scandinavian Journal of Laboratory Animal Science, v.38, n.2, p.117-27, 2011.

RASLAN, D.S., Jamal, C.M., Duarte, D.S., Borges, M.H., De Lima, M.E. Anti-PLA2 action test of Casearia sylvestris Sw. Bolletino Chimico Farmaceutico, v.141, n.6, p.457-60, 2002.

RAURAMMA, R., Kuusela, P., Hietanen, E. Adipose, muscle and lung tissue lipoprotein lipase activities in young streptozotocin treated rats. Hormone and Metabolic Research, v.12, n.11, p.591-5, 1980.

REAVEN, E.P., Reaven, G.M. Mechanisms for development of diabetic hypertriglyceridemia in streptozotocin-treated rats: effect of diet and duration of insulin deficiency. Journal of Clinical Investigation, v.54, n.5, p.1167-78, 1974.

RIBNICKY, D.M., Poulev, A., Schimidt, B., Cefalu, W.T., Raskin, I. Evaluation of botanicals for improving human health. American Journal of Clinical Nutrition, v.87, n.2, p.472-5, 2008.

RIZOS, E., Tambaki, A.P., Gazi, I., Tselepis, A.D., Elisaf, M. Lipoprotein-associated PAF-acetylhydrolase activity in subjects with the metabolic syndrome. Prostaglandins, Leukotrienes and Essential Fatty Acids, v.72, n.3, p.203-9, 2005

RUPPELT, B.M., Pereira, E.F., Gonçalves, L.C., Pereira, N.A. Pharmacological screening of plants recommended by folk medicine as anti-snake venom-I. Analgesic and anti-inflammatory activities. Simões, C.M., Falkenberg, M., Mentz, L.A., Schenkel, E.P., Amoros, M., Girre, L., 1999. Antiviral activity of south Brazilian medicinal plant extracts. Phytomedicine 6, 205-214.

Memorias do Instituto Oswaldo Cruz, v.86, suppl.2, p.203-5, 1991.

SALTIEL, A.R., Kahn, R. Insulin signalling and the regulation of glucose and lipid metabolism. Nature, v.414, n.6865, p.799-806, 2001.

SCHOENFELDER, T., Pich, C.T., Geremias, R., Avila, S., Daminelli, E.N., Pedrosa, R.C., Bettiol, $\mathrm{J}$. Antihyperlipidemic effect of Casearia sylvestris methanolic extract. Fitorerapia, v.79, n.6, p.465-7, 2008.

DA SILVA, S.L., Calgarotto, A.K., Chaar, J.S., Marangoni. S. Isolation and characterization of ellagic acid derivatives isolated from Casearia sylvestris SW aqueous extract with anti-PLA(2) activity. Toxicon, v.52, n.6, p.655-66, 2008.

SIMÕES, C. M. O.; Schenkel, E. P.; Gosmann, G.; Mello, J. C. P.; Mentz, L. A.; Petrovick, P. R. Farmacognosia: da planta ao medicamento. $5^{a}$ ed. Porto Alegre/ Florianópolis: Editora da UFRGS/Editora da UFSC, 2004.

SUNG, J.H., Lee, S.J., Park, K.H., Moon, T.W. Isoflavones inhibit 3-hydroxy-3-methylglutaryl coenzyme A reductase in vitro. Bioscience, Biotechnology, and Biochemistry, v.68, n.2, p.428-32, 2004.

TAVANGAR, K., Murata, Y., Pedersen, M.E., Goers, J.F., Hoffman, A.R., Kraemer, F.B. Regulation of lipoprotein lipase in the diabetic rat. Journal of Clinical Investigation, v.90, n.5, p.1672-8, 1992.

TININIS, A.G.; Assonuma, M.M.; Telascrea, M.; Perez, C.C.; Silva, M. R.S.R.M.; Favoreto, R.; Cavalheiro, A.J. Composição e variabilidade química de óleo essencial de Casearia sylvestris Sw. Revista Brasileira de Plantas Medicinais, v.8, n.4, p.132-136, 2006.

VATS, V., Yadav, S. P., Grover J. K. Ethanolic extract of Ocimum sanctum leaves partially attenuates streptozotocin-induced alterations in glycogen content and carbohydrate metabolism in rats. Journal of Ethnopharmacology, v.90, n.1, p.155-60, 2004.

VERMANI, K., Garg, S. Herbal medicines for sexually transmitted diseases and AIDS. Journal of Ethnopharmacology, v.80, n.1, p.49-66, 2002.

WOOD, R.J., Volek, J.S., Davis, S.R., Dell'Ova, C., Fernandez, M.L. Effects of a carbohydrate-restricted diet on emerging plasma markers for cardiovascular disease. Nutrition \& Metabolism, v.3, n.19, 2006.

YOUNG, N.L., Lopez, D.R., McNamara, D.J. Contributions of absorbed dietary cholesterol and cholesterol synthesized in small intestine to hypercholesterolemia in diabetic rats. Diabetes, v.37, n.8, p.1151-6, 1988. 